\title{
特別企画 健康増進の食品微生物学
}

Food Microbiology for Health Promotion

\section{プロバイオティクスの臨床応用}

Clinical Application of Probiotics

高木陽 光

Akimitsu TAKagI

(Yakult Central Institute, Yakult Honsha Co., Ltd., 5-11 Izumi, Kunitachi-shi, Tokyo, 186-8650)

\section{1. はじめに}

「国民の健康寿命が延伸する社会」の構築が重要政策 として示されているが, 食品微生物は, この大きな課題 の実現に向けて，さまざまな形で利用できるものと期待 される，食品微生物の中にはプロバイオテイクスと呼ば れる集団がある.プロバイオティクスの定義として, 「腸内フローラ (細菌叢) のバランスを改善することに よりヒトに有益な作用をもたらす生きた微生物」が広く 受け入れられている。プロバイオティクスによる疾患予 防効果が臨床試験で確認され，その作用機序が示されつ つある．筆者の所属組織では，「予防医学」と，腸を丈 夫にすることが健康で長生きにつながる「健腸長寿」の 理念の下で, 種々の研究を実践している。，それらの中か ら, 腸内フローラの形成に関わる研究や, 代表的なプロ バイオティクスであるLactobacillus casei Shirota（乳酸 菌シロ夕株：LcS）を用いた臨床研究を中心に，その一 部を紹介する。

\section{2. 腸内フローラと健康}

ヒトの腸内には 1,000 種，100兆個の腸内細菌が常在 しており，高度に制御された生態系（腸内フローラ，腸 内細菌叢，消化管マイクロバイオーム）を形成している ことから，七トは腸内細菌と共生しているといえる．近 年，さまざまな疾患で腸内フローラの異常 (dysbiosis)を 伴うことが明らかになりつつあることから，消化管の生 態系の健全な状態が心身の健康につながると考えられつ つある．腸内フローラを構成する細菌の中で，食品微 生物として利用されている代表的なものには, 乳酸菌 (Lactobacillus属) やビフィズス菌（Bifidobacterium属） が知られている.

胎内は無菌環境であるが，新生児は出生直後から環境 中の微生物に曝露され，細菌が腸内に定着する。母乳栄 養児の腸内フローラにおいて，ビフィズス菌は優勢であ る．新生児の腸内に定着するビフィズス菌の由来につい ては，母親の腸内フローラや母乳が伝播するものと考え

画186-8650 東京都国立市泉 5-11
られてきたが，母から子への菌株の伝播は実証されてい なかった，牧野らは，母親と新生児の臯便からビフィズ 又菌を単離し, 各菌株の遺伝子配列の解析により菌株間 の同一性を，遺伝子配列が一致するかを解読することで， ビフィズス菌の母子伝播を菌株レベルで検証した ${ }^{14)}$. その結果, 自然分婏で出産した母子に扔いて, 出産前の 母親とそれぞれの乳児の糞便から同一系統のビフィズス 菌株が分離された。これらの中には，出生直後から 3 か 月後まで経時的に検出された菌株も認められた。これに 反して, 帝王切開で出産した母子ではビフィズス菌の母 子伝播は観察されなかった。 帝王切開で出生した新生児 では, ビフィズス菌の定着は自然分娩児より遅く, 生後 1か月を過ぎる頃に，菌数は少ないものの定着が観察さ れた ${ }^{14)}$ 。これらの結果は, 自然分婏の過程で母親のビ フィズス菌が新生児に伝播して, 腸内で増殖し定着する ことを示しており，母から子への菌株の伝播が実証され た.

ところで，ビフィズス菌は母乳に多く含まれる乳糖や オリゴ糖などを資化して乳酸や酢酸を産生することから， 腸内環境と健康の維持に重要と考えられている。 また, 新生児に扔けるビフイズス菌の早期定着は，生涯にわた る宿主の健康へ寄与することが指摘されているが，ビ フィズス菌は加齢とともに減少する。したがって，腸内 細菌であるビフィズス菌を食品微生物として産業利用し, 摄取により腸内に補充する考えは合理的と考えられる。

\section{3. プロバイオティクス, 運動, 免疫と上気道感染}

プロバイオティクスの定義として, 英国の微生物学者 Fullerが1989年に提唱した「腸内フローラのバランス を改善することによりヒトに有益な作用をもたらす生き た微生物 $\rfloor^{5)}$ が広く受け入れられている。また，「十分量 を撖取したときに宿主に有益な効果を与える生きた微生 物」(FAO/WHO) という定義も公表されている. 近年, プロバイオティクスによる疾患予防効果が多数の臨床試 験で確認され，その作用機序が示されつつある.

プロバイオティクスには，多くの乳酸菌が含まれてい る。そのようなプロバイオティクス菌株の一つである Lactobacillus casei Shirota（乳酸菌シロ夕株：LcS）は, 
80 年以上の食経験があるプロバイオティクスであり，そ の作用機序が腸内環境あるいは宿主免疫系などにおいて 実証されている，免疫系は，感染およびがんを含むさま ざまな疾患を制御するうえで重要な役割を果たす。すな わち免疫機能の低下は, それらの疾患リスクを増大させ る。ところで，アスリートには健康的な印象を伴うが, 過度な運動の直後には一過性の免疫機能の低下（非自己 細胞を傷害するナチュラルキラー (NK) 細胞の活性低下) が知られており ${ }^{3)}$ ，また，マラソン大会の参加者におい ては，マラソンが上気道感染のリスクを上昇させること が報告されている ${ }^{19)}$ アアスリートにおける $\mathrm{LCS}$ 含有発酵 乳の継続飲用の上気道感染に対する効果が検討され ${ }^{6)}$, LcS群またはプラセボ群に無作為化されたアスリートに, 二重盲検法で 4 か月間, $\operatorname{LcS}$ 含有発酵乳またはプラセボ を連日投与した結果，上気道感染の罹患率はLcS群で有 意に低下した ${ }^{6)}$

一方，高齢者では若齢者に比べて免疫機能が低下し， 上気道感染のリスクが高まるが，LcS 含有発酵乳の継続 飲用により上気道感染の発症率の低下傾向や症状の緩和 が観察されている ${ }^{4,30)}$ 。さらに，精神的なストレスが高 いと予想される健常者の集団として 30〜49歳の内勤の 会社員を対象に同様な試験を行ったところ，LcS含有発 酵乳による上気道感染率の有意な低下が認められた ${ }^{22)}$. この集団において，プラセボ群では上気道感染率が上昇 した時期にNK活性が低下したものの, LcS群では NK 活性は低下せずに維持された ${ }^{22)}$ 。これらの結果は, LcS 含有発酵乳の飲用は, 上気道感染の発症率の低下や症状 の軽減に有効であることを支持している.

\section{4. プロバイオティクスとストレスと脳腸相関}

上述したアスリートにおける過度な運動は，身体に とってはストレスでもあり，ストレス関連物質の免疫機 能への影響も指摘されている。 日常生活で遭遇するさま ざまなストレスは，身体機能の不調を引き起こす。スト レスに対する検討として, 進級試験を控えた健常な医学 部生を対象に, $\operatorname{LcS}$ 含有発酵乳を飲用させる試験を行っ た ${ }^{24)}$ 。試験日が近づくと不安感の高まりと唾液中のコル チゾール（副腎皮質ホルモンで過剩なストレスにより多 量に分泌される）の上昇を認めたが, LcSの飲用により 唾液中コルチゾールの上昇が有意に抑えられ，体調不良 を訴える被験者数が減少した。非臨床の急性ストレスモ デルにおいては，LcSの投与により血中コルチコステロ ン（副腎皮質ホルモン）の上昇が抑制された。加えて, $\mathrm{LcS}$ の投与は胃の求心性迷走神経活動を活発化させ，脳 の弧束核における c-Fos 陽性神経細胞を増加させた ${ }^{24)}$. これらの結果は，プロバイオティクスが腸管神経を刺激 して，その情報を脳に伝達し（脳腸相関）, 精神的な安定 を促す可能性を支持している。これらのエビデンスを基 にLcSには，腸内環境の改善機能に加えて，本試験に用 いられた LcSを含む飲料に対して，ストレスの緩和，睡
眠の質の向上について, 機能性表示が認可された.

\section{5. シンバイオティクスとバクテリアルトランスロ ケーションとがん}

以前より LcSの臨床効果は, がんや感染の領域で多く 検討されている。消化器がん領域の手術後の感染予防に おいては近年, LcSにビフィズス菌ヤクルト株とビフィズ ス菌が資化する（プレバイオティクスと呼ぶ）難消化性 ガラクトオリゴ糖を加えた混合物（シンバイオテイクス） の投与による, 術後の感染性合併症の軽減に関するエビ デンスが蓄積され, 周術期管理への臨床応用が始まって いる ${ }^{13)}$ ，胆道がん患者における肝切除では，術後に一 般治療の経腸栄養剂に併せて同シンバイオティクスが投 与された ${ }^{10)}$ 。一般治療の単独群では患者の糞便中に感 染症起因菌 (Enterobacteriaceae, Candida, Psuedomonas aeruginosa)の検出量の増加が検出されたが，一般治療 に同シンバイオティクスの投与を併用した群では，その 増加は有意に低減され，術後感染性合併症が有意に減少 した ${ }^{10)}$ 。こうした, 術後感染性合併症の低減作用は, 術 前から同シンバイオティクスを投与したほうが，より効 果的であることが独立した試験で確認された ${ }^{23)}$. 一方, 食道がん患者に対する術前化学療法（ドセタキセル, シ スプラチン，5-FUの3凨併用）においては，化学療法開 始時より前の期間から同シンバイオティクスを投与され た群のほうが，院内処方の乳酸菌整腸剂を同期間に投与 された対照群と比べて, 腸球菌, ブドウ球菌, 緑膿菌の 検出が有意に低減しており, 発熱性好中球減少症や下痢 の発症が有意に減少した ${ }^{15)}$ 。同様な効果は, 腹腔鏡下大 腸手術においても検討され，糞便中の総有機酸，酢酸， $\mathrm{pH}$ と言った消化管内環境の改善も確認されている ${ }^{11,12)}$. 術後感染症は, 消化管バリア機能の破綻（リーキーガッ ト）ならびにバクテリアルトランスロケーション (BT) により発症するが, LcSを含む同シンバイオティクスの 作用機序として非臨床研究により，BTの予防ならびに腸 管上皮の夕イトジャンクションにおける細胞間接着因子 (Claudin-1, Occludin, ZO-1) の発現元進が確認されてい る ${ }^{1)}$. BTは2型糖尿病患者でも確認されており, LcS含 有発酵乳あるいはプレバイオテイクスであるガラクトオ リゴ糖の飲用による改善が確認されている7, 21). した がって，腸内フローラによる腸内環境の保全が，腸管バ リア機能の保持に重要な機能であると考えられる.

\section{6. プロバイオティクスとがん}

統計から，日本人の 2 人に 1 人ががんを発症する， 3 人 に1人ががんで死亡する，と言われて久しい。がんの罹 患率は一般的に加齢とともに増加するが, 超高齢化社会 に向かっている状況で, いかにしてがんを予防するか, 根治治療を実現するか, 発症しても適切な治療でがんと 共存するかは，大きな課題である，がんにおいては，よ り予防に直接的と考えられる発症や再発に関連する臨床 
表1. がん患者を対象としたL. casei Shirotaの臨床試験*

\begin{tabular}{lcccc}
\hline \multirow{2}{*}{ がんの種類 } & \multicolumn{3}{c}{ 研究の類別 } & \multicolumn{2}{c}{ (類別) 参考論文 } \\
\cline { 2 - 4 } & $\mathrm{A}^{*}$; 介入研究 & B; 疫学研究 & C; 作用機序研究 & \\
\hline 膀胱がん & 実施済み & 実施済み & 実施済み & (A) Aso Y., 1995. ${ }^{18)}$ (A) Naito S., 2008. ${ }^{19)}$ (B) Ohashi Y., 2002. ${ }^{20)}$ \\
大腸がん & 実施済み & 未実施 & 実施中 & (A) Ishikawa H., 2005. ${ }^{21)}$ \\
乳がん & 未実施 & 実施済み & 実施中 & (B) Toi M., 2013. ${ }^{24)}$ \\
\hline
\end{tabular}

*: 副作用の管理研究を除く, *: 切除後の再発予防試験.

エビデンスが蓄積されている (表1)。膀胱がんでは, 切 除後の再発抑制におけるプラセボ対照試験 ${ }^{2)} お$ おび抗 がん郕との併用試験 ${ }^{18)}$ に加えて, 疫学研究としてケー スコントロール (症例対照) 研究が実施されている20). その症例対照研究では, LcSを含有する発酵乳飲料の習 慣的な飲用に対して, 膀胱がんへの罹患を抑制する可能 性が示されている ${ }^{20)}$. 臨床に扔いて実践的と考元られ る，抗がん剂との併用試験では，表在性膀胱がんと診断 された患者を対象とした，3年間の膀胱内の無再発率を 主評価項目とした前向き無作為化比較試験が25施設共 同で実施された ${ }^{18)}$ ．経尿道的電気切除術 (transurethral resection)を受け腫瘍を完全に切除された患者は，アン トラサイクリン系抗がん剤のエピルビシン (epi-ADR)の 膀胱内注入を術後治療として受けた。epi-ADRの単独治 療群と, epi-ADR 治療にLcSの経口摂取を加えた併用群 に打ける3年間の無再発率は, 前者が $59.9 \%$ で後者が $74.6 \%$ であり，併用群で有意に高かった $(p=0.0234)^{18)}$.

大腸がん（結直腸腺腫性ポリープ）ではポリープ切除 後の再発抑制が, 前向きコホート研究で示されている ${ }^{8)}$. 内視鏡でポリープを切除した患者にLcSの介入が行われ， 経過観察が実施された。2年目の内視鏡検査では，長径 $4 \mathrm{~mm}$ 以上の腫瘍の発生率が介入により有意に抑制され ていた． 4 年目の検查では, 高異型度大腸がんの発症率 は有意に抑制されており，LcS服用群が $34.4 \%$, 非服用 群が $45.2 \%$ であった ${ }^{8)}$. 服用による宿主免疫系への作用 や，腸内環境の改善など，詳細な作用機序の解明が期待 された。

欧米と比較して, 乳がんの発症率は日本を含むアジア 地域では低い，その理由の一つには大豆に含まれるイソ フラボンの摂取量と乳がんの発症の間に逆相関が見られ ることから ${ }^{31}$, 当該地域で多い大豆の摂取量の乳がん抑 制への関与が考えられており，同様な逆相関は，本邦に 打けるコホート研究でも示されている ${ }^{32}$. ᄂかしながら, 本邦に扩ける乳がんの発症率は過去 20 年で急増している. 本邦の早期乳がんに打ける症例対照研究が実施され，大 豆摂取を含む生活習慣や乳がん発症のリスク因子などが 40〜55歳の女性を対象として調査された ${ }^{29)}$. その結果は, 大豆イソフラボンの摂取量の多少に分けて解析され，大 豆イソフラボンの摂取量が多い群ほど乳がん発症オッズ 比は低く, 当該研究に打いても大豆摂取による乳がん予 防の可能性が示された. 本研究では, 大豆摂取に加えて,
LcSを含む飲料の 10 歳からの習慣的な飲用についても調 べられ，摂取頻度が高い群（週4回以上）で最も発症率が 低かった。 大豆イソフラボンの揁取量の多い群 (43.75 $\mathrm{mg}$ 以上）では発症リスクは $51 \%$ 低下し, LcSの摂取頻 度が高い群では発症リスクが50\%低下した。興味深いこ とに，LcS㧍よび大豆イソフラボンを共に多く損取して いた集団の乳がん発症リスクが最も低值を示した（64\% 低下 $)^{29)}$ 。この両者の併用効果については, 我々の実施 した非臨床研究から, 両因子の異なる作用機序に起因す るものと推察されたが9), 詳細な作用機序の解明が乳が ん予防の実践には必要と考えられる。 ところで，大豆イ ソフラボンの吸収には, 腸内細菌による基質の代謝（ア グリコン化）が必須である。 そこで，LcSで豆乳を発醳 させた発酵豆乳を考案し上市した。その飲料を用いた健 常な女性における単回飲用試験では, 摂取後のイソフラ ボンの血中濃度が豆乳より高いこと ${ }^{17)}$, 同様な反復飲用 試験では, 腸内フローラの変容が確認された ${ }^{16)}$. 同じ処 方に準じて実験室で調製した発酵豆乳で我々は，非臨床 研究で乳がんの発症抑制を確認しており ${ }^{26)}$ ，また，LCS の免疫系を介したがんの発症抑制も異なるモデルで確認 している ${ }^{25,27,28)}$.

がんの進行は患者を死に至らせるため，がんの早期発 見と早期治療の重要性が指摘されて久しい。近年は，が んの免疫チェックポイント機構が, がん治療に扔いて注 目されているが，さまざまなアプローチにプロバイオ ティクスやシンバイオティクスを組み合わせることで, がん制御の精度を高めうると期待される。

\section{7. おわりに}

健康寿命の延伸にプロバイオティクスが寄与しうるか については, 臨床への応用が可能な科学的根拠を基盤と した産業利用がその鍵を握ると考えられる。実験モデル とは異なり，ヒトという集団は地域差や個人差などの多 様性に富んでいるが，個人レベルに打いても腸内フロー ラは多様性に富んでいる，がんのような疾患に扔いては 同一の腫瘍組織の内部に扔いても不均質性が高く，制御 を困難とする要因の一つとなっている，現状では，腸内 フローラと健康との密接な関係が明らかにされつつある が，今後は，集団に対するビッグデー夕解析などにより， 健康に関する複数の要因の因果関係が明らかにされるも のと期待される.プロバイオティクスが安全でありヒト 
の健康に有用であることを誰もが享受できるよう，より 深い作用機序への理解と有効性を支持する根拠の蓄積に 向けて取り組んでいきたい

\section{参考文献}

1) Asahara, T., Takahashi, A., Yuki, N., Kaji, R., Takahashi, T. and Nomoto, K.: Protective effect of a synbiotic against multidrug-resistant Acinetobacter baumannii in a murine infection model. Antimicrob. Agents Chemother., 60, 3041-3050 (2016)

2) Aso, Y., Akaza, H., Kotake, T., Tsukamoto, T., Imai, K. and Naito, S.: Preventive effect of a Lactobacillus casei preparation on the recurrence of superficial bladder cancer in a double-blind trial. The BLP Study Group. Eur. Urol., 27, 104-109 (1995).

3) Berk, L. S., Nieman, D. C., Youngberg, W. S., Arabatzis, K., Simpson-Westerberg, M., Lee, J. W., Tan, S. A. and Eby, W. C.: The effect of long endurance running on natural killer cells in marathoners. Med. Sci. Sports Exerc., 22, 207-212 (1990).

4) Fujita, R., Iimuro, S., Shinozaki, T., Sakamaki, K., Uemura, Y., Takeuchi, A., Matsuyama, Y. and Ohashi, Y.: Decreased duration of acute upper respiratory tract infections with daily intake of fermented milk: a multicenter, doubleblinded, randomized comparative study in users of day care facilities for the elderly population. Am. J. Infect. Control, 41, 1231-1235 (2013).

5) Fuller, R.: Probiotics in man and animals. J. Appl. Bacteriol., 66, 365-378 (1989).

6) Gleeson, M., Bishop, N. C., Oliveira, and M., Tauler, P. Daily probiotic's (Lactobacillus casei Shirota) reduction of infection incidence in athletes. Int. J. Sport. Nutr. Exerc. Metab., 21, 55-64 (2011).

7) Gonai, M., Shigehisa, A., Kigawa, I., Kurasaki, K., Chonan, O., et al.: Galacto-oligosaccharides ameliorate dysbiotic Bifidobacteriaceae decline in Japanese patients with type 2 diabetes. Benef. Microbes, 8, 705-716 (2017).

8) Ishikawa, H., Akedo, I., Otani, T., Suzuki T, Nakamura T, et al: Randomized trial of dietary fiber and Lactobacillus casei administration for prevention of colorectal tumors. Int. J. Cancer, 116, 762-767 (2005).

9) Kaga, C., Takagi, A., Kano, M., Kado, S., Kato, I., et al.: Lactobacillus casei Shirota enhances the preventive efficacy of soymilk in chemically induced breast cancer. Cancer Sci., 104, 1508-1514 (2013).

10) Kanazawa, H., Nagino, M., Kamiya, S., Komatsu, S., Mayumi, T., et al.: Synbiotics reduce postoperative infectious complications: a randomized controlled trial in biliary cancer patients undergoing hepatectomy. Langenbecks Arch. Surg., 390, 104-113 (2005).

11) Komatsu, S., Sakamoto, E., Asahara, T., Nomoto, K. and Nagino, M.: Effects of synbiotics on ileal microbiota. Indian J. Med. Res., 147, 58-65 (2018).

12) Komatsu, S., Sakamoto, E., Norimizu, S., Shingu, Y., Asahara, T., Nomoto, K. and Nagino, M.: Efficacy of perioperative synbiotics treatment for the prevention of surgical site infection after laparoscopic colorectal surgery: A randomized controlled trial. Surg. Today, 46, 479-490 (2016).

13) Komatsu, S., Yokoyama, Y. and Nagino, M.: Gut microbiota and bacterial translocation in digestive surgery: the impact of probiotics. Langenbecks Arch. Surg., 402, 401-416 (2017).

14) Makino, H., Kushiro, A., Ishikawa, E., Kubota, H., Gawad, A., et al: Mother-to-infant transmission of intestinal bifidobacterial strains has an impact on the early development of vaginally delivered infant's microbiota. PLOS ONE, 8, e78331 (2013).

15) Motoori, M., Yano, M., Miyata, H., Sugimura, K., Saito, T., et al.: Randomized study of the effect of synbiotics during neoadjuvant chemotherapy on adverse events in esophageal cancer patients. Clin. Nutr., 36, 93-99 (2017).

16) Nagino, T., Kaga, C., Kano, M., Masuoka, N., Anbe, M., et al.: Effects of fermented soymilk with Lactobacillus casei Shirota on skin condition and the gut microbiota: a randomised clinical pilot trial. Benef. Microbes, 9, 209-218 (2018).

17) Nagino, T., Kano, M., Masuoka, N., Kaga, C., Anbe, M., et al.: Intake of a fermented soymilk beverage containing moderate levels of isoflavone aglycones enhances bioavailability of isoflavones in healthy premenopausal Japanese women: a double-blind, placebo-controlled, single-dose, crossover trial. Biosci. Microbiota. Food Health, 35, 9-17 (2016).

18) Naito, S., Koga, H., Yamaguchi, A., Fujimoto, N., Hasui, Y., Kuramoto, H., Iguchi, A., Kinukawa, N., and Kyushu University Urological Oncology Group.: Prevention of recurrence with epirubicin and Lactobacillus casei after transurethral resection of bladder cancer. J. Urol., 179, 485-490 (2008).

19) Nieman, D. C., Johanssen, L.M., Lee, J. W. and Arabatzis, K.: Infectious episodes in runners before and after the Los Angeles Marathon. J. Sports Med. Phys. Fitness, 30, 316-328 (1990).

20) Ohashi, Y., Nakai, S., Tsukamoto, T., Masumori, N., Akaza, H., et al: Habitual intake of lactic acid bacteria and risk reduction of bladder cancer. Urol. Int., 68, 273280 (2002).

21) Sato, J., Kanazawa, A., Azuma, K., Ikeda, F., Goto, H., et al.: Probiotic reduces bacterial translocation in type 2 diabetes mellitus: A randomised controlled study. Sci. Rep., 7, 12115 (2017).

22) Shida, K., Sato, T., Iizuka, R., Hoshi, R., Watanabe, O., Igarashi, T., Miyazaki, K., Nanno, M. and Ishikawa, F.: Daily intake of fermented milk with Lactobacillus casei strain Shirota reduces the incidence and duration of upper respiratory tract infections in healthy middleaged office workers. Eur. J. Nutr., 56, 45-53 (2017).

23) Sugawara, G., Nagino, M., Nishio, H., Ebata, T., Takagi, K., Asahara, T., Nomoto, K. and Nimura, Y.: Perioperative synbiotic treatment to prevent postoperative infectious complications in biliary cancer surgery: A randomized controlled trial. Ann. Surg., 244, 706-714 
(2006).

24) Takada, M., Nishida, K., Kataoka-Kato, A., Gondo, Y., Ishikawa, H. et al: Probiotic Lactobacillus casei strain Shirota relieves stress-associated symptoms by modulating the gut-brain interaction in human and animal models. Neurogastroenterol. Motil., 28, 1027-1036 (2016).

25) Takagi, A., Ikemura, H., Matsuzaki, T., Sato, M., Nomoto, K., Morotomi, M. and Yokokura, T.: Relationship between the in vitro response of dendritic cells to Lactobacillus and prevention of tumorigenesis in the mouse. J. Gastroenterol., 43, 661-669 (2008).

26) Takagi, A., Kano, M. and Kaga, C.: Possibility of breast cancer prevention: use of soy isoflavones and fermented soy beverage produced using probiotics. Int. J. Mol. Sci., 16, 10907-10920 (2015).

27) Takagi, A., Matsuzaki, T., Sato, M., Nomoto, K., Morotomi, M. and Yokokura, T.: Enhancement of natural killer cytotoxicity delayed murine carcinogenesis by a probiotic microorganism. Carcinogenesis, 22, 599-605 (2001).

28) Takagi, A., Matsuzaki, T., Sato, M., Nomoto, K., Morotomi, M. and Yokokura, T.: Inhibitory effect of oral ad- ministration of Lactobacillus casei on 3-methylcholanthrene-induced carcinogenesis in mice. Med. Microbiol. Immunol., 188, 111-116 (1999).

29) Toi, M., Hirota, S., Tomotaki, A., Sato, N., Hozumi, Y., et al.: Probiotic beverage with Soy isoflavone consumption for breast Cancer prevention: A case-control study. Curr. Nutr. Food Sci., 9, 194-200 (2013).

30) Van, Puyenbroeck, K., Hens, N., Coenen, S., Michiels, B., Beunckens, C., Molenberghs, G., Van, Royen, P. and Verhoeven, V.: Efficacy of daily intake of Lactobacillus casei Shirota on respiratory symptoms and influenza vaccination immune response: a randomized, doubleblind, placebo-controlled trial in healthy elderly nursing home residents. Am. J. Clin. Nutr., 95, 1165-1171 (2012).

31) Wu, A. H., Yu, M. C., Tseng, C. C. and Pike, M. C.: Epidemiology of soy exposures and breast cancer risk. Br. J. Cancer, 98, 9-14 (2008).

32) Yamamoto, S., Sobue, T., Kobayashi, M., Sasaki, S., Tsugane, S. and Japan Public Health Center-Based Prospective Study on Cancer Cardiovascular Diseases Group.: Soy, isoflavones, and breast cancer risk in Japan. J. Natl. Cancer Inst., 95, 906-913 (2003). 